\title{
Bruk av kvantemedisin i strid med etiske regler for leger
}

\author{
En lege er innklaget til Rådet for legeetikk for å tilby kvantemedisinsk
} behandling i sin praksis. Klager mener at dette er kvakksalveri og at slik behandling ikke må gis legitimitet gjennom at autoriserte leger går god for den. Videre utrykker han bekymring for at legens pasienter utnyttes og ikke mottar tilfredsstillende behandling, og i verste fall at pasienter lider overlast.

Innklagede lege har redegjort for at hun stort sett driver vanlig medisinsk praksis, men med et komplementært tilsnitt, bl.a. benytter hun seg av kvantemedisinsk behandling. Hun mener metodene er tilfredsstillende dokumentert og er nyttige $i$ behandlingen av enkelte pasienter, særlig kronikere som ikke får noe tilbud og ellers blir stemoderlig behandlet i helsevesenet. Hun skriver videre: «Felles for alle disse metodene er at man bruker devices som henter ut info fra pasienten, som tillater oss å sende signaler tilbake som regulerer homeostasen.»

Rådet for legeetikk har vurdert innklagedes bruk av kvantemedisinske metoder ut fra etiske regler for leger, kapittel I, $\S 9$, 2. ledd, som bl.a. sier: «Legen må ikke gjøre bruk av eller anbefale metoder som savner grunnlag i vitenskapelige undersøkelser eller tilstrekkelig medisinsk erfaring.»
I denne vurderingen har Rådet fått Vinjar Fønnebø, direktør ved Nasjonalt forskningssenter innen komplementær og alternativ medisin (NAFKAM), Universitetet i Tromsø, til å vurdere den vitenskapelige dokumentasjonen for de angitte kvantemedisinske metodene. Fønnebø konkluderer i sin utredning med at den dokumentasjon som er fremlagt, ikke gir grunnlag for å hevde at metodene har vist seg effektive i diagnostikk og behandling av sykdom.

\section{Rådets vedtak}

\section{Rådet vedtok å uttale:}

«Rådet tviler ikke på innklagede leges oppriktige ønske og mål om å benytte de kvantemedisinske metodene til beste for sine pasienter. Til forsvar for å ta i bruk utradisjonelle metoder kan det hevdes at mye av akseptert medisinsk diagnostikk og behandling også savner god vitenskapelig dokumentasjon. Rådet anerkjenner at medisinsk praksis ofte baserer seg mer på erfaring og tradisjon enn på streng vitenskapelig dokumentasjon. Det er imidlertid under den forutsetning at slike metoder gjøres til gjenstand for etterprøving etter aksepterte vitenskapelig metoder med det mål å gjøre klinisk praksis mest mulig kunnskapsbasert. Rådet anser det som særlig viktig at nye undersøkelses- og behandlingsprinsipper ikke tas i bruk i vanlig legepraksis før effekt og mulige bivirkninger er tilstrekkelig vitenskapelig dokumentert. Ut fra den dokumentasjonen som foreligger, mener rådet at de kvantemedisinske metodene som innklagede lege benytter, ikke oppfyller de nødvendige kravene til dokumentasjon. Derfor ble konklusjonen at det er i strid med etiske regler for leger, kapittel I, $\S 9$, 2. ledd å anbefale og å bruke dem i diagnostikk og behandling. Rådet vil derfor uttale kritikk overfor innklagede lege.»

\section{Trond Markestad}

Rådet for legeetikk

Oppgitte interessekonflikter: Ingen

Manuskriptet ble mottatt 26.3. 2009 og godkjent 2.7. 2009. Medisinsk redaktør Anne Kveim Lie. 